\title{
Relationship between principals' emotional intelligence and instructional leadership practices in Malaysian secondary schools
}

\author{
Shafinaz A. Maulod ${ }^{1}{ }^{*}$, Chua Yan Piaw ${ }^{1}$, Shahrin Alias ${ }^{2}$, Leong Mei Wei ${ }^{1}$ \\ 1Institute of Educational Leadership, University of Malaya, 50603 Kuala Lumpur, Malaysia \\ 2Institute Aminuddin Baki, Ministry of Education, 71760 Bandar Enstek, Nilai, Negeri Sembilan, Malaysia
}

\section{A R T I C L E I N F O}

\section{Article history:}

Received 8 November 2016

Received in revised form

15 January 2017

Accepted 18 January 2017

\section{Keywords:}

Emotional intelligence

Instructional leadership

Educational leaders

Leadership

\begin{abstract}
A B S T R A C T
School principal emotional intelligence is necessary to enable schools being led effectively due to the changes taking place in education system lately. This study aims to explore the relationship between principal emotional intelligence and instructional leadership practices in Malaysian secondary schools. This is a non-experimental quantitative research using survey technique through the administration of a set of questionnaire that compromised demographic variables, principal emotional intelligence competency and instructional leadership practices. 396 returned questionnaires have been analyzed in this research. The findings showed that teachers perceived their principals practice high level of instructional leadership and emotional intelligence competency. Furthermore, data indicated that there was statistically significant positive correlation which is strong between principal emotional intelligence and instructional leadership practices. In addition, multiple regression analysis showed that relationship management, social awareness and self-awareness being the three emotional intelligence competencies that are statistically significant predictors of principal instructional leadership practices. The implications of this study could be used as a guide to school leaders in managing and controlling their emotions when dealing with the various parties to produce outstanding and excellence schools.
\end{abstract}

(C) 2017 The Authors. Published by IASE. This is an open access article under the CC BY-NC-ND license (http://creativecommons.org/licenses/by-nc-nd/4.0/).

\section{Introduction}

Education plays a key role for the economic development and the development of a country. When education is seen as one of the factors that determine the success (critical success factor) to transform Malaysia into a developed country, the Ministry of Education constantly makes improvements in the education system. Improvements were made including by creating an Education Development Master Plan (PIPP, 20062010) and the Malaysian Education Blueprint (PPPM 2013-2025) which aims to improve the quality of education in Malaysia to keep pace with the needs of global education to produce competitive human resources and has high market value. School is led by a principal and the members are consisting of teachers and students. Teachers need a leader who can inspire and motivate them to be more effective

\footnotetext{
* Corresponding Author

Email Address: finazmaulod@gmail.com (S. A. Maulod) https://doi.org/10.21833/ijaas.2017.03.019

2313-626X/C 2017 The Authors. Published by IASE.

This is an open access article under the CC BY-NC-ND license

(http://creativecommons.org/licenses/by-nc-nd/4.0/D
}

in teaching while students will rely heavily on teachers to acquire knowledge and skills. Therefore, the effectiveness of the school is highly dependent on the leadership of the principal (Rowena, 2014) because their attitude is decisive to the effective implementation of the program. Principals are the leaders who played an important role in the achievement of excellence or success of a school. Leadership often has to do with how to use power and style of leadership that is owned by a leader. Among these skills is the ability to control emotions and skills as an instructional leader which allows the principals to influence teachers to carry out teaching process effectively. In this regard, the ability of the principal to manage emotional intelligence and leadership style is important in determining the success of a school.

Leadership practices exist in the context of social leadership and effective leader needs high emotional intelligence (Abdul, 2007; Goleman, 2001; Nurul et al., 2013). Hallinger (2008), one of the pioneers of instructional leadership expressed a combination of interpersonal and intrapersonal skills to assist in the development effectiveness of principals as instructional leaders. The interpersonal 
and intrapersonal skills highlighted are among the dimensions contained in emotional intelligence competency. In Malaysia, study related to instructional leadership is becoming increasingly important to create effective schools. However, the impact of emotional intelligence on instructional leadership behavior is still limited in Malaysia.

The focus of this study is to which extent of emotional intelligence affect the role of principal as instructional leader? Therefore, an understanding of the role of emotional intelligence in influencing instructional leadership behaviors are expected to provide information of value to the practice of leadership that supports teaching and learning process and provide an additional input to the leadership of the school effectiveness literature.

Therefore, principals as instructional leaders need to know how to motivate teachers to be more effective in teaching through how he effectively manage and control his emotions first. On top of this, instructional leader needs to have interpersonal and communication skills effectively to produce excellent organization. Without those skills, vision and mission designed will not be achieved (Rahimah and Gavifekr, 2014). As an instructional leader, principal needs to communicate effectively with teachers and students so that each instructional design will be successfully implemented. This is important as school leadership is basically instructional leadership where the main focus is teaching and learning process in the classroom. Effective leader requires a profound knowledge of human psychology to understand and lead the diverse personalities of the organization (Dinham, 2005; Najibah, 2015).

A principal task was found to be in varieties including the need for long-term working time (Juhana, 2007) led to the pressure is the result of their need to respond to the needs of various parties which sometimes create conflict. This is a continuation of the requirements in the national education system and the increasing demand due to external pressures such as the will of the people. Any changes in the education system require the power and emotion regulation in order to avoid disappointment and pressure on citizens especially school principals and teachers. Principals as leaders in schools should be able to identify his emotion and the teachers under his leadership for creating a culture of mutual trust and openness in relations. Through a clear understanding of emotions allows principals to work with teachers to achieve school mission. Thus, the diversity of this task requires principal to have control and balanced his emotional intelligence.

Thus, based on the problems stated, this study is important because research on emotional intelligence and school leaders rarely done especially in Malaysia (Abdul, 2007) as well as recommendations by Hebert (2011) and Cliffe (2011) which encourages more research conducted to investigate the relationship between emotional intelligence and leadership in schools. Most of the studies conducted are related to the general leadership in the field of industry, banking and business view to profit (profit) while education is classified in the non-profitable fields.

Goleman (2001) defined emotional intelligence as the ability to recognize own feelings and the feelings of others, the ability to motivate and manage the emotions of his own and others better. The importance of emotional intelligence is divided on the importance of social aspects, education and leadership. Goleman et al. (2002) saied that emotional intelligence can lead to success, whether at home, school or in the workplace. Goleman (2000, 2001) stated that an individual's success in life is dependent on only $20 \%$ of the intelligence quotient (IQ) and the remaining $80 \%$ is dependent on the emotional quotient (EQ). Previous studies conducted by several researchers have shown the importance of emotional intelligence of leaders in influencing their leadership effectiveness (Syarif, 2014). Leaders who have a high level of emotional intelligence show that effective leadership behavior and influencing followers to excel. In the business sector, emotional intelligence can improve the performance of a leader. According to Singh (2006), Singh and Dali (2013), emotional intelligence is important in the business world but less study conducted to examine the relationship between instructional leadership and emotional intelligence. The impact and influence of emotional intelligence on instructional leadership of principals is less known although researchers (Beatty, 2007; Dinham, 2005; Zepeda, 2006) have identified the importance of emotional intelligence to produce effective instructional leaders. Studies have also shown that individuals who exhibit a high level of emotional intelligence managed to lead the organization effectively (Abdul, 2007; Yulk, 2013). Theory and model of emotional intelligence that has been used as the main reference in this study is the model of emotional intelligence by Goleman (2001). He has combined components of personal and social competence to produce four main dimensions:

- Self-awareness,

- Self-management,

- Social-awareness and

- Relationship management.

Meanwhile, instructional leadership is a concept that emphasizes leadership behaviors and activities that directly affect student achievement involving principals as academic leaders as its main pillars. According to Hallinger (2011), principals as instructional leaders in schools should work together to define school's mission (the first dimension) related to student achievement. Principals should be able to shape inspiring school missions and developing a consensus toward achieving them. The missions of the school are built to be understood and can be applied by teachers because it influences their commitment, motivation and abilities. Besides, the missions that have been 
produced should be explained and communicated to all members of the school, including teachers, students and parents. This is consistent with a study done by Mendels (2012) which found effective leadership starts from the process of defining the mission and vision that led to the high commitment of the school community. The second dimension is managing instructional program which requires the involvement of teachers in curriculum and teaching process directly. Hallinger (2011) defined managing instructional program as supervising and evaluating instructional programs, curriculum coordinate and monitor the progress of students. The third dimension is promoting positive school learning climate which refers to the norms and behaviors of teachers and students that affect the whole teaching and learning process in schools.

The purpose of this study is to investigate the relationship between principal emotional intelligence and instructional leadership practices based on the perception of teachers. The research questions are as follows:

1. What is the level of principal emotional intelligence in Negeri Sembilan secondary schools?

2. What is the level of principal instructional leadership practices in Negeri Sembilan secondary schools?

3. Is there a significant relationship between emotional intelligence and principal instructional leadership practices in Negeri Sembilan secondary schools?

4. Which of the principal emotional intelligence dimensions are the significant predictors of principal instructional leadership practices in Negeri Sembilan secondary schools?

5. Does the proposed structural model consisting of principal emotional intelligence and instructional leadership practices fit with the data collected from Negeri Sembilan secondary schools?

The conceptual framework of this study is shown in Fig. 1.

\section{Methodology}

This study applied quantitative research method using survey technique through the administration of a set of questionnaire. The targeted population was comprised of all public secondary school teachers in Negeri Sembilan, Malaysia. The sample in this study is based on a stratified random sampling. This sampling technique is suitable for obtaining a sample from a large population (Babbie, 2016). Of the 500 questionnaires distributed, only 396 $(79.2 \%)$ were used as real samples in the study. Instrument used in this study is divided into three parts. Part A is questionnaire related to the demographics of the respondents such as age, gender, grade of service and work experience, Part B is questionnaire on principal emotional intelligence from Emotional Competencies Inventory (ECI-V2) by Boyatzis et al. (2001), which contains 72 items and Part C is a survey of instructional leadership practices based on Principals Instructional Management Rating Scale (PIMRS) by Hallinger (2011) consisted of 50 items. Data were analyzed using the Statistical Package for the Social Sciences (SPSS) and Analysis of Moment Structures (AMOS). Both descriptive and inferential statistical methods were used to analyze the data to answer the proposed research questions.

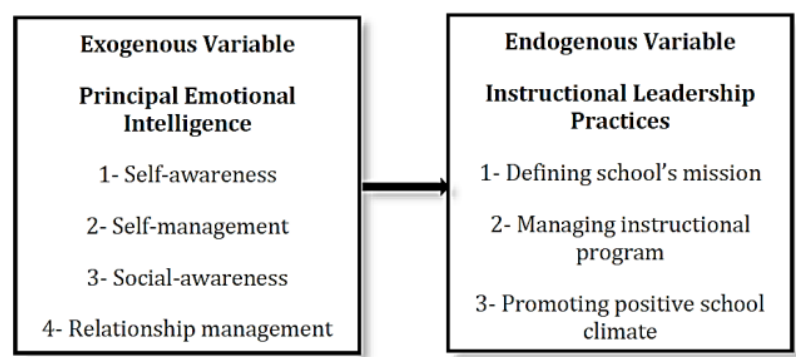

Fig. 1: Conceptual framework of the study

\section{Results and discussion}

The results of this study are presented according to each of the research questions.

\subsection{First research question}

The first research question is about the level of principal emotional intelligence in Negeri Sembilan secondary schools.

Descriptive statistic was used to analyze the data collected from 396 teachers and the results are shown in Table 1.

Table 1: Mean, standard deviation and the level of principal emotional intelligence ( $\mathrm{N}=396)$

\begin{tabular}{cccc}
\hline Dimension & Mean & Standard Deviation & Level \\
\hline Relationship management & 7.20 & 1.273 & High \\
Self-management & 7.01 & 1.322 & High \\
Social Awareness & 6.82 & 1.398 & High \\
Self-awareness & 6.77 & 1.309 & High \\
Overall & 7.00 & 1.271 & High \\
\hline
\end{tabular}

Table 1 presents the overall mean for principal emotional intelligence according to the perception of teachers is 7.00. This indicates that the level of principal emotional intelligence in Negeri Sembilan is at high level $(M=7.00, S D=1.271)$. There are two dimensions which are self-management $(\mathrm{M}=7.01$,
$\mathrm{SD}=1.322)$ and relationship management $(\mathrm{M}=7.20$, $\mathrm{SD}=1.273$ ) have higher mean than the overall mean $(M=7.00)$. While the dimension of self-awareness $(\mathrm{M}=6.77, \mathrm{SD}=1.309)$ and social awareness dimension $(\mathrm{M}=6.82, \mathrm{SD}=1.398)$ showed lower mean than the overall mean of principal emotional 
intelligence competency. However, all the four principal emotional intelligence competency dimensions have means that are interpreted as high level. Teachers in Negeri Sembilan secondary schools rated their principals as demonstrating high level of emotional intelligence competency. These findings support previous studies conducted by Nik (2013), Mohd (2005) that the level of emotional intelligence principals on the whole was at a high level. This finding was consistent with the findings of a study conducted by Munroe (2009) who found that school leaders in Michigan have high level of emotional intelligence for the four dimensions and the highest dimension is self-management. He believes to be an effective school leaders, self-management should come first in order to manage and control his emotions in relation to teachers, students and staff in the organization.

The study also found that the highest level of emotional intelligence is for relationship management dimension, which are one's skills to get the desired response from his followers. Relationship management is important and the behavior exhibited by leaders are such as 1) influence others-the ability of leaders to persuade and influence other people's emotions; 2) inspiration-a leader who constantly inspire and guide individuals and team members to work together towards achieving the shared mission without coercion and teamwork and collaboration- the ability of a leader to build a spirit of cohesion, cooperation, help each other to achieve common goals collectively.

According to Goleman (2001) for a person to be successful in life and one's job requires more than just intellectual intelligence (IQ). Not only in the construct of emotional intelligence related to someone working conditions, but also provides a conceptual understanding of the organization as a whole. Emotional intelligence is the distinguishing factor between an excellent leader and not an excellent leader. When a leader has a stable emotional intelligence, the leader is able to control his emotions and behaviors as well as better understand and have a good relationship with his followers to have successful organization. Therefore, emotional intelligence competencies of school leaders are the key elements that should be included in the planning program and strengthening school leadership skills to achieve one of Malaysian Education Blueprint missions that are to make sure those schools in lead by high performance principal.

\subsection{Second research question}

The second research question is about the level of principal instructional leadership practices in Negeri Sembilan secondary schools. Results are shown in Table 2.

Table 2: Mean, standard deviation and the level of principal instructional leadership practices $(\mathrm{N}=396)$

\begin{tabular}{cccc}
\hline Dimension & Mean & Standard Deviation & Level \\
\hline Defining School's Missions & 7.70 & 1.302 & High \\
Managing Instructional Program & 7.18 & 1.376 & High \\
Promoting Positive School Learning Climate & 6.99 & 1.429 & High \\
Overall & 7.19 & 1.304 & High \\
\hline
\end{tabular}

Table 2 shows that principal instructional leadership practices of secondary schools in the state is at a high level $(\mathrm{M}=7.19, \mathrm{SD}=1.304)$ based on the perception of teachers. The dimension defining school's mission $(\mathrm{M}=7.70, \mathrm{SD}=1.302)$ has higher mean than the overall mean $(M=7.19)$, while the dimensions of managing instructional program $(\mathrm{M}=$ $7.18, \mathrm{SD}=1.376$ ) and dimension promoting positive school learning climate $(\mathrm{M}=6.99, \mathrm{SD}=1.429)$ have lower mean than the overall mean. However, all of the dimensions that represent instructional leadership practices showed higher mean values and prove that the principals in Negeri Sembilan demonstrate high instructional leadership practices. The highest mean value is the dimension defining school's missions followed by the dimensions of managing instructional program and promoting positive school learning climate. The level of principal instructional leadership practices are also at high level for all the three dimensions namely defining school's mission, managing instructional programs and promoting positive school learning climate. Simin et al. (2015) and Jameela (2012) in their studies also found that principal instructional leadership practices were at high level.
The result of this study indicated that the highest level of principal instructional leadership practices is from defining school's missions. Similar finding was also reported by Mendels (2012), Munroe (2009) and Nik et al. (2015). Mission and vision shared by the school members help create collaboration and cooperation in achieving the goals set. This is supported by Baldoni (2012) that as instructional leader a principal should lead with purpose not only to have goals to be achieved by the organization but sharing it with his subordinates is the most important. Thus, the principal as a leader and the main source of the instructional process must be fluent and clear about the aims of the school in order to be understood and communicated to the school community including stakeholders (Sekhu, 2011).

Principals as leaders for leading teaching and learning process should have a high commitment to practice instructional leadership to ensure the effectiveness of teaching and learning across the school to increase the commitment of teachers to teach and students to learn. According to studies conducted earlier principals who play the role of instructional leadership will be able to influence the behavior of teachers in teaching and motivate 
students in learning (Simin et al., 2015; Tschannen and Gareis, 2015), high job satisfaction among teachers. Besides, according to Hallinger (2012) principals influence student achievement indirectly through his role as instructional leaders. This is supported by Rosmaniar and Marzuki (2016) who found that school principals should practice instructional leadership effectively because principals are important in the success and effectiveness of teaching and learning process that takes place in the classroom. Principal as instructional leaders should constantly monitor the performance of students, identify and discuss the strengths and weaknesses of teachers and students together to design programs that can help improve their performance.

\subsection{Third research question}

The third research question is about the significant relationship between principal emotional intelligence and instructional leadership practices in Negeri Sembilan secondary schools.

To examine the relationship between principal emotional intelligence and instructional leadership practices, researchers performed the Pearson product-moment correlation test and result of the analysis is presented in Table 3.

Table 3: Pearson product-moment correlation analysis between principal emotional intelligence and instructional leadership practices $(\mathrm{N}=396)$

\begin{tabular}{cccc}
\hline Dimension & \multicolumn{3}{c}{ Instructional Leadership } \\
\hline & $\mathrm{r}$ & $\mathrm{r}^{2}$ & Sig** $^{*}$ \\
\cline { 2 - 4 } Self-awareness & 0.785 & 0.616 & 0.000 \\
Self-management & 0.808 & 0.653 & 0.000 \\
Relationship management & 0.819 & 0.671 & 0.000 \\
Social Awareness & 0.796 & 0.634 & 0.000 \\
Emotional Intelligence & 0.834 & 0.696 & 0.000 \\
\hline
\end{tabular}

Pearson correlation analysis was carried out to investigate the relationship between principal emotional intelligence and instructional leadership practices shows that the relationship between the two variables is statistically significant and positive ( $\mathrm{r}=0.834, \mathrm{p}<0.01$ ) as shown in Table 3 . The strength of the correlation between the principal emotional intelligence and instructional leadership practices is strong. The variance $\left(r^{2}=0.696\right)$ showed that $69.6 \%$ of the overall change in principals' instructional leadership practices is caused by emotional intelligence. While another $30.4 \%$ changes may be caused by other factors which are not included in this study.

The conclusion of the findings above indicate that teachers in Negeri Sembilan believes there is a statistically significant and positive relationship between principal emotional intelligence and instructional leadership practices in which the strength of the correlation is at a strong level. It proves in this study that principal emotional intelligence affects the instructional leadership practices. The findings explained that principal with high levels of emotional intelligence will demonstrate high instructional leadership practices in Negeri Sembilan secondary schools.

The findings of this study show that emotional intelligence is important in influencing principals' instructional leadership practices in Negeri Sembilan secondary school. Principals who have high emotional intelligence will demonstrate high level of instructional leadership practices. In addition, the ability of a principal to identify, manage and control emotions can determine the effectiveness of the performance of the school as the principal role is more complex and has a wide scope in which the principals have to treat a variety of human nature that is difficult to control and expected. Therefore, the skills to manage emotions is very important in the relationship between leaders and followers and not just rely on the knowledge gained from reading or leadership courses attended (Rowena, 2014). School leaders who are able to work in a positive mood can improve the quality of teachers and staff in order to produce effective schools.

\subsection{Forth research question}

The forth research question is about the principal emotional intelligence dimensions are the significant predictors of instructional leadership practices in Negeri Sembilan secondary schools.

Multiple regression analysis is used by researchers to answer the research question above.

Results of the multiple regression analysis (stepwise) shown in Table 4 indicated that from the four dimensions of principal emotional intelligence, only three dimensions, namely self-management, social-awareness and self-awareness correlate and contribute significantly $(69.8 \%)$ to the instructional leadership practices of secondary schools principals in Negeri Sembilan.

The dominant predictor for principal instructional leadership practices is relationship management $(\beta=0.442, t=6.179$ and $p=0.000)$. The t-test result was significant at the significant level of $\mathrm{p}<0.05$ with the $\mathrm{R}^{2}=0.672$, this indicated that the relationship management contributes $67.2 \%$ of variance on principal instructional leadership practices.

From the standardized beta value result, when relationship management dimension increases by one unit of standard deviation, principal instructional leadership practices will increase by 4.42 unit of standard deviation. The second predictor which contributed only $2.2 \%$ of variance in principal 
instructional leadership practices is social awareness dimension $(\beta=0.267, \mathrm{t}=4.117$ and $\mathrm{p}=0.000)$. The third predictor that contributed only $0.4 \%$ of variance in principal instructional leadership practices is self-awareness dimension $(\beta=0.4157, \mathrm{t}$ $=2.347$ and $\mathrm{p}=0.019$ ) (Table 5).

Table 4: Multiple regression (stepwise) on principal emotional intelligence to instructional leadership practices

\begin{tabular}{ccccccc}
\hline Variable & $\mathrm{B}$ & $\beta$ & $\mathrm{t}$ & $\mathrm{Sig} \mathrm{t}$ & $\mathrm{R}^{2}$ & $\%$ \\
\hline Relationship Management & 0.452 & 0.442 & 6.179 & 0.000 & 0.672 & 67.2 \\
Social-awareness & 0.249 & 0.267 & 4.117 & 0.000 & 0.694 & 2.2 \\
Self-awareness & 0.157 & 0.157 & 2.347 & 0.019 & 0.698 & 0.4 \\
Constant & 1.172 & & 5.616 & 0.000 & & \\
\hline
\end{tabular}

\begin{tabular}{cccccc}
\multicolumn{6}{c}{ Table 5: Multiple regression analysis (stepwise): ANOVA } \\
\hline \multicolumn{7}{c}{ Sum of Square } & df & Mean Square & F & Sig \\
\hline Regression & 468.77 & 3 & 156.255 & 302.108 & 0.000 \\
Residual & 202.75 & 392 & 0.517 & & \\
Total & 671.52 & 395 & & & \\
\hline
\end{tabular}

Based on Table 5, the F-test result indicated that there is a significant relationship between the three predictor variables with principal instructional leadership practices $[F(3,392)=302.108, p<0.05]$ at the significant level of $\mathrm{p}<0.05$. This multiple regression analysis results also showed that the combination of the three dimensions of principal emotional intelligence namely self-management, social-awareness and self-awareness accounted for $69.8 \%$ of the variance in principal instructional leadership practices. This means that there are as many as $30.2 \%$ of the variance on principal instructional leadership practices are unable to be predicted by principal emotional intelligence as it may be caused by other variables (factors) that are not examined in this study.

According to Sun et al. (2014), an outstanding principal not only requires the skills to manage alone but also require emotional intelligence skills such as self-management, empathy, influence and decisionmaking skills to meet the needs of teachers so that they are more committed to teaching. This is proven by the findings of this study which indicate that relationship management dimension is a key predictor of instructional leadership practices. Relationship management must be controlled by school leaders to manage every member of the organization effectively through teamwork, conflict management, catalyze the necessary changes, able to develop and influence members in the organization as well as inspire the school community. This finding supports research carried out by Nik (2013), Nurul et al. (2013) and Sun et al. (2014). Relationship management is an important element to overcome the problem of change in an organization (Nurul et al., 2013). This finding reflected that relationship between principals, teachers and students is important to ensure that the school missions can be achieved. Building relationships involve the ability to control emotions. It helps a good interaction with people around and be able to influence them in resolving any conflicts that arise.

\subsection{Fifth research question}

The fifth research question is about the proposed structural model of principal emotional intelligence and instructional leadership practices fitness with the data collected from Negeri Sembilan secondary schools.

Result from the SEM analysis is shown in Fig. 2. The model is developed to predict the relationship between principal emotional intelligence and instructional leadership practices of Negeri Sembilan secondary schools.

Confirmatory factor analysis (CFA) for model measurements are pre-requisite to be fulfilled before testing the structural equation modeling (SEM) to ensure that the indicator actually represents the construct to be measured in the study (Byrne, 2010; Hair et al., 2010).

CFA measurement model is implemented to examine the relationship between indicators of latent variables. AMOS software was used for analysis of CFA besides testing the validity and reliability of the research instrument (Byrne, 2010; Hair et al., 2010). Convergent validity is fulfilled when the weighting factor (factor loading) is significant and have a value more than 0.50 and discriminant validity is fulfilled when the correlation between each factor is not more than 0.90 (Hair et al., 2010).

When the value of convergent and discriminant validity are not met, the item should be dropped. Next, a structural equation model for predicting relationship between principal emotional intelligence and instructional leadership practices was analyzed and shown in Fig. 2.

From the SEM analysis conducted (Fig. 2), the model fit with the data collected from the samples significantly. The fitness indexes have achieved the threshold values needed [RMSEA $=0.060(<0.08)$, the index GFI $=0.979(>0.90), \mathrm{CFI}=0.995(>0.90)$ and Ratio Chisq/df $=2.405(<5.0)]$. Factor loadings for all the constructs are between 0.89 and 0.97 indicate no problem exists and convergent validity of the correlation $\left(R^{2}\right)$ excess of 0.40 , as recommended by Hair et al. (2010). The standardized beta value for principal emotional intelligence on instructional leadership practices is $0.86(\beta=0.86)$. The result of this study also show the direct effect of emotional intelligence to principals' instructional leadership is statistically significant. This indicated that when principal emotional intelligence (PEI) increases by one standard deviation, principal instructional 
leadership practices (PIL) would increase $0.86 \quad$ standard deviation.

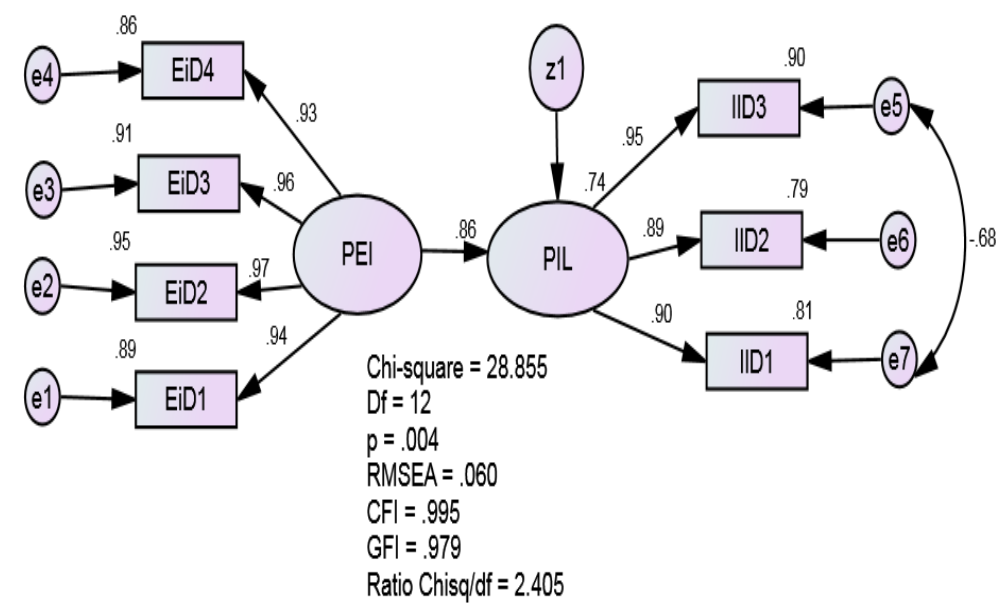

Note: EiD1-self-awareness, EiD2-self management, EiD3-relationship management, EiD4-social awareness, IlD1-defining school's missions, IlD2-managing instructional program and IlD3-promoting positive school learning climate

Fig. 2: The Structural Model of principal emotional intelligence (PEI) and instructional leadership practices (PIL) fit with the data collected from Negeri Sembilan secondary schools

Besides that, the squared multiple correlation $\left(\mathrm{r}^{2}=0.74\right)$ for principal instructional leadership practices is 0.740 where the effect size is large, indicated that $74 \%$ of the variance in principal instructional leadership practices could be predicted by principal emotional intelligence. Therefore, another $26 \%$ of the variance in principal instructional leadership practices is unable to be predicted by principal emotional intelligence which may be caused by other variables (not examined in this study).

\section{Conclusion}

The effectiveness of emotional intelligence in an organization should be taken seriously by all members of the organization. Based on empirical studies, emotional intelligence influence the effectiveness of the leadership (Goleman et al., 2002; Mohd, 2004; Palmer et al., 2001; Wong and Law, 2002), change management (Mohd, 2004), subordinate emotion and feeling (Prati, 2004), individual performance and attitude to work (Wong and Law, 2002), job satisfaction and organizational commitment (Adeyemo, 2008), the performance of principals (Cook, 2006) and the success of the organization's financial management. According to Goleman (2000) emotional intelligence of leaders such as self-confidence, self-orientation, initiative, empathy, teamwork and collaboration have positive impact on the climate and organizational performance. He has proved that for a person to be successful in life and one's job requires more than just intellectual intelligence (IQ). Emotional intelligence is not only able to identify the feelings of themselves but also the feelings of others, motivate and manage their own emotions and relationships with others. The concept of leadership has undergone many changes over time as a result of the diversity of backgrounds, education and behavior within the school community. Managing, directing and controlling the specification and task alone can no longer be practiced in schools. Organizations such as schools that want to maintain and continue its excellence requires excellent resource management should see emotional intelligence as a complement to school leaders and catalysts in developing teachers and students as suggested in the Malaysian Education Development Plan (PPPM 2013-2025). In terms of management, school leaders play an important role as a driving force, liaison, entrepreneurs and problem solvers that require skills in controlling their emotional intelligence. Therefore the understanding of self-emotional intelligence and school leadership emotional intelligence is very important where emotional intelligence management of principal in a school is the key aspects that need to be considered. Lastly, it is hoped that results of this study seek to help increase the body of knowledge, particularly in the field of educational leadership.

\section{Acknowledgment}

The authors are grateful to Ministry of Education and Institute of Educational Leadership, University Malaya for providing and supporting this research.

\section{References}

Abdul GA (2007). Emotional intelligence and leadership effectiveness of school managers in Malaysia. Educationist, 1(2): 75-81.

Adeyemo DA (2008). Demographic characteristics and emotional intelligence among workers in some selected organisations In Oyo State, Nigeria. The Journal of Business Perspective, 2(1): 43-48.

Babbie E (2016). The basics of social research. Cengage Learning, Boston, USA.

Baldoni J (2012). The leaders pocket guide: 101 indispensible tools, tips and techniques for any situation. Barnes and Noble, New York, USA.

Beatty B (2007). Going through the emotions: Leadership that gets to the heart of school renewal. Australian Journal of Education, 51(3): 328-340. 
Boyatzis RE, Goleman D, and HayGroup (2001). The Emotional Competence Inventory (ECI). HayGroup, Boston, USA.

Byrne BM (2010). Structural equation modelling with AMOS: Basic concepts, applications, and programming. Routledge, Manitoba, Canada.

Cliffe J (2011). Emotional intelligence: A study of female secondary school headteachers. Educational Management Administration and Leadership, 39(2): 1-14.

Cook CR (2006). Effects of emotional intelligence on principals' leadership performance. Ph.D. Dissertation, Montana State University, Montana, USA.

Dinham S (2005). Principal leadership for outstanding educational outcomes. Journal of Educational Administration, 43(4): 338356.

Goleman D (2000). Working with emotional intelligence. Bantam Books, New York, USA.

Goleman D (2001). The emotionally intelligent workplace. Bantam Books, New York, USA.

Goleman D, Boyatzis R, and McKee A (2002). Primal leadership: Realizing the power of emotional intelligence. Harvard Business School Press, Boston, USA.

Hair JF, Anderson RE, Babin BJ, and Black WC (2010). Multivariate data analysis. Prentice Hall, New Jersey, USA.

Hallinger P (2008). Methodologies for studying school leadership: A review of 25 years of research using the principal instructional management rating scale. In the Annual Meeting of the American Educational Research Association, New York, USA: $1-48$.

Hallinger P (2011). A review of two decades of research on the principalship using the principal instructional management rating scale. Educational Administration Quarterly, 47(2): 271-306.

Hallinger P (2012). Assessing and developing instructional leadership in schools. In: Shen J (Eds.), Tools for improving the principalship: 47-69. Peter Lang., Oxford, UK.

Hebert EB (2011). The relationship between emotional intelligence, transformational leadership and effectiveness in school principals. Ph.D. Dissertation, Georgia State University, Atlanta, USA.

Jameela BA (2012). Instructional leadership practices among Pahang state school principals: A qualitative study. Ph.D. Dissertation, National University of Malaysia, Selangor, Malaysia.

Juhana Z (2007). Relationship between principal workload and instructional leadership practices in Muar district secondary schools. M.Sc. Thesis, University of Technology Malaysia, Johor, Malaysia.

Mendels P (2012). The effective principal: 5 pivotal practices that shape instructional leadership. Journal of Staff Development, 33(1): 54-58.

Mohd AY (2004). Emotional intelligence competencies and the impact on organizational effectiveness. Jurnal Pengurusan Awam, 3(1): 21-26.

Mohd HH (2005). Emotional intelligence profile of secondary school principals in Kota Baharu, Kelantan. M.Sc. Thesis, University of Malaya, Kuala Lumpur, Malaysia.

Munroe MD (2009). Correlation of emotional intelligence and instructional leadership behaviors. Ph.D. Dissertation. University of Phoenix, Arizona, USA.

Najibah MD (2015). Job satisfaction and its relationship with emotional intelligence. Ph.D. Thesis, Northern University of Malaysia, Kedah, Malaysia.
Nik MMA, Mohd RT, Hazlina J, Wan ARMS, and Mohd NO (2015). Principals' Instructional Leadership and Teachers' Commitment in Three Mara Junior Science Colleges (Mjsc) in Pahang, Malaysia. Procedia Social and Behavioral Sciences, 191: 1848-1853.

Nik RI (2013). Effect of emotional intelligence competence behaviour towards transformational leadership style of cooperative committee in Selangor schools. Ph.D. Thesis, University of Malaya, Kuala Lumpur, Malaysia.

Nurul HMN, Maarof R, Hanina H, and Ibrani AA (2013). Model fitness on emotional intelligence, personality traits and leadership behavior on job performances. Jurnal Teknologi, 61(1): 47-55

Palmer B, Walls M, Burgess Z, and Stough C (2001). Emotional intelligence and effective leadership. Leadership and Organisational Development Journal, 22(1): 5-10.

Prati IM (2004). Emotional intelligence as facilitator of emotional labour process. Ph.D. Dissertation, The Florida State University College of Business, USA

Rahimah A and Ghavifekr S (2014). School leadership for the 21st century: A conceptual review. Malaysian Online Journal of Educational Management, 2(1): 48-61.

Rosmaniar W and Marzuki SCBH (2016). Headmaster instructional leadership and organizational learning on the quality of madrasah and the quality of graduates the State Madrasah Aliyah at Jakarta capital region. Higher Education Studies, 6(1): 159-168.

Rowena M (2014). EQ, not just IQ: The relationship between emotional intelligence and the success of high school principals who have been awarded the Illinois Principals Association's high school principal of the year award. Ph.D. Dissertation, Loyola University Chicago, USA.

Sekhu MS (2011). Practices of primary school principals as instructional leaders: Implications for learner achievement. M.Sc. Thesis, University of Pretoria, South Africa.

Simin G, Ibrahim MS, Chellapan K, Sukumaran K, and Subramaniam A (2015). Instructional leadership practices of principal in vocational and technical college: Teachers' perception. Malaysian Online Journal of Educational Management, 3(1): 48-67.

Singh D (2006). Emotional intelligence at work: a professional guide. Response Book, New Delhi, India.

Singh P and Dali CM (2013). Need for emotional intelligence to develop principals' social skills. African Education Review, 10(3): 502-519.

Sun H, Wang X, and Sharma S (2014). A study on effective principal leadership factors in China. International Journal of Educational Management, 28(6): 716-727.

Syarif $H$ (2014). Analysis of the emotional intelligence influences, leadership style and interpersonal communication on the decision making by principals of state junior high schools in South Jakarta, Indonesia. International Journal of Latest Research in Science and Technology, 3(4): 22-30.

Tschannen MM and Gareis CR (2015). Faculty trust in the principal: An essential ingredients in high-performing schools. Journal of Educational Administration, 53(1): 66-92.

Wong CS and Law KS (2002). The effects of leader and follower emotional intelligence on performance and attitude: An exploratory study. Leadership Quarterly, 13(3): 243-274.

Yulk G (2013). Leadership in organizations. Pearson, New York, USA.

Zepeda SJ (2006). High-stakes supervisions: We must do more. International Journal of Leadership in Education, 9(1): 61-73. 